\title{
POLICY OPTIONS TO LOWER RICE PRICES IN INDONESIA
}

\section{Pilihan Kebijakan Untuk Menurunkan Harga Beras di Indonesia}

\author{
Hizkia Respatiadi, Hana Nabila \\ Center for Indonesian Policy Studies (CIPS), Grand Wijaya Center No. F-59 Kebayoran Baru, \\ Jakarta Selatan, DKI Jakarta 12160 Indonesia \\ email: hizkia.respatiadi@cips-indonesia.org
}

Naskah diterima: 28/09/2017; Naskah direvisi: 01/03/2018; Disetujui diterbitkan: 21/06/2018 Dipublikasikan online: 31/07/2018

\begin{abstract}
Abstrak
Di Indonesia, harga beras membuat 28 juta masyarakat pra-sejahtera menghabiskan nyaris separuh penghasilannya. Menanggapi hal ini, pemerintah menerapkan Harga Eceran Tertinggi (HET) dan menugaskan Badan Urusan Logistik (Bulog) untuk menstabilkan harga beras. Sebagai salah satu perwujudan tugasnya, Bulog ditunjuk menjadi importir tunggal beras. Kajian ini menganalisis efektifitas HET, kinerja Bulog sebagai importir beras, dan korelasi antara harga beras di Indonesia dan pasar internasional. Penelitian ini mengusulkan opsi kebijakan untuk menurunkan harga beras dengan menggarisbawahi potensi perdagangan internasional. Dengan menggunakan Error Correction Model (ECM) dan hasil wawancara. Hasilnya: (1) HET menekan para pedagang eceran, sementara para tengkulak, pemilik penggilingan, dan pedagang grosir yang mengambil laba terbesar dari sistem distribusi beras dalam negeri; (2) Akibat kendala birokrasi, Bulog kerap mengimpor beras ketika harga internasional sudah telanjur meningkat; (3) Harga beras di Indonesia terdeviasi dan lebih mahal dibandingkan pasar internasional. Penelitian ini merekomendasikan agar pemerintah mengkaji HET, memberikan kebebasan kepada Bulog untuk menentukan waktu maupun kuantitas beras yang perlu diimpornya dengan berdasarkan pada analisis pasar, dan membentuk forum konsultasi dengan sektor swasta yang memenuhi syarat. Hal ini akan menjaga harga beras senantiasa kompetitif baik bagi konsumen maupun pedagang eceran, serta akan membawa Indonesia lebih dekat dengan rantai nilai regional.
\end{abstract}

Kata Kunci: Perdagangan Beras, Sistem Distribusi, Korelasi Harga Domestik dan Internasional, Harga Eceran Tertinggi, Sektor Swasta

\begin{abstract}
In Indonesia, rice prices cost around 28 million poor nearly half of their income. In response, the government implements price ceiling (HET) and assigns National Logistics Agency (Bulog) to stabilize rice prices. As part of its duties, Bulog was appointed as the sole rice importer. This study analyzed the effectiveness of HET, Bulog's performance as rice importer, and the correlation between rice prices in Indonesia and in international market. This studi explores policy options to lower rice prices by highlighting the potential of international trade. This study used Error Correction Models (ECM) and semi-structured interviews. The results: (1) HET pressures retailers, while middlemen, rice millers, and wholesalers benefit the most from domestic rice distribution; (2) Due to bureaucratic constraints, Bulog frequently imported rice when international prices were already rising; (3) Rice prices in Indonesia deviate away from and higher than the international market. This study recommends the government to review $\mathrm{HET}$, to give freedom to Bulog to determine the timing and quantity of rice importation based on its market analysis, and to organize consultative forums with qualified private sector. This will keep the prices competitive for both consumers and retailers and bring Indonesia closer to the regional value chain.
\end{abstract}

Keywords: Rice Trade, Distribution System, Domestic-International Price Correlation, Price Ceiling, Private Sector

JEL Classification: F1, F4, H4, H5 


\section{INTRODUCTION}

Rice is the staple food for most Indonesian people with the annual national consumption estimated at around 45.7 million tons (OECD and FAO, 2015). According to the joint report of OECD and FAO (2015), the annual rice consumption per capita in Indonesia is $163 \mathrm{~kg}^{1}$, higher than some other Asian countries such as Thailand (142.5 kg), China $(76.4 \mathrm{~kg})$, and India $(73.4 \mathrm{~kg})$. Meanwhile, the National SocioEconomic Survey conducted by Statistics Indonesia recorded the rice consumption per capita reached up to $1.56 \mathrm{~kg}$ per week, or estimated at 81.4 $\mathrm{kg}$ per year (Statistics Indonesia, 2017b). With such high demand, rice prices have significant impact on the livelihood of many Indonesian people, especially those with low income.

Currently,

there

are approximately 28 million poor people residing in the country with the average monthly income of IDR 300,000 (The World Bank, 2015). Meanwhile, the national average of rice prices in early May 2017 reached IDR 10,600 (USD 0.8) per kg (Ministry of Trade, 2017), which is twice of the World Bank reference - that use Thai rice - during the same period (The World Bank, 2017). At this price, combined with the consumption level mentioned before, we could statistically estimate that each poor person spends approximately $47.9 \%$ of their monthly income on rice.

A. Domestic rice distribution system in Indonesia

The Indonesian government argues that rice high prices is due to the long distribution chain of domestic rice in the country (Ariyanti, 2016; Jefriando, 2016). As illustrated in Figure 1, rice from the farmers must go through at least five different distribution actors before it could reach the consumers.

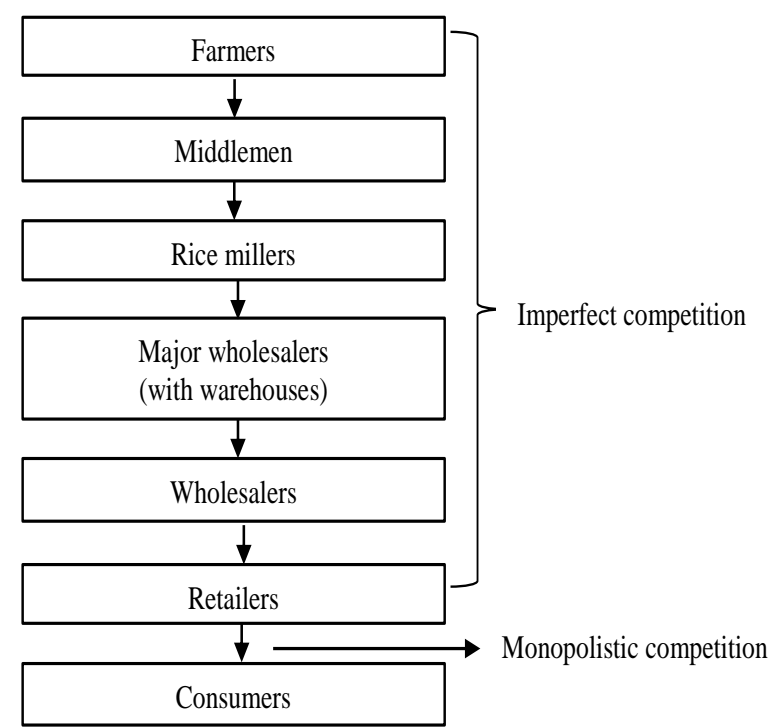

Figure 1. Levels of Domestic Rice Distribution in Indonesia

Source: KPPU (2016)

1 The estimated number is generated from Food Balance Sheets (UN-FAO, 2001) 
Indonesian Competition Commission (Komisi Pengawas Persaingan Usaha/KPPU) (2016) states that imperfect and monopolistic competitions are part of domestic rice distribution system in Indonesia. Imperfect competition refers to two different situations. At the level of farmers, middlemen, and rice millers, it refers to the situation where the purchasing actors (e.g. the middlemen) collude and agree among themselves to buy the rice from the selling actors (e.g. the farmers) at a predetermined price, regardless of the market price at that moment. At the wholesaler levels, imperfect competition refers to oligopolistic competition where only a handful of corporations control the distribution process (Bhinadi, 2012), and therefore, control the prices as well (Pradana, 2015).

Meanwhile,

monopolistic competition in the retailers-consumers level relates to the situation where despite the number of retailers in the market, there is little to no difference in prices between retailers in the same area, mostly due to the oligopolistic competition between the wholesalers mentioned above (KPPU, 2016). The government attempts to address this issue by imposing state control on both domestic and international trade of rice.
B. Price ceiling policy

On the domestic trade, the government implements price ceiling policy (Harga Eceran Tertinggi/HET) at IDR 9,500 per kg from 2016. This price serves as the maximum retail price for the consumers as stipulated in the Regulation of the Minister of Trade (MOT) 63/2016, which then later renewed in MOT 27/2017.

To implement price ceiling policy, the government assigns Bulog to conduct market monitoring activity called Market Operations (Operasi Pasar) (Ministry of Trade, 2016). This activity aims to ensure all retailers sell their rice to the consumers without exceeding the maximum price as stipulated in the current regulation, and failure to comply would result in their licenses being revoked (Masa, 2017). According to the officials from the Ministry of Trade, this policy serves as an indicator when the government needs to intervene in the market (Interviews, 21 March 2017).

C. Rice import monopoly by Bulog

On the international trade, the government restricts rice importation as it argues that it needs to balance between ensuring the farmers' welfare and keeping the prices affordable for the consumers (Presidential Office, 2017). The government expects the price 
ceiling policy to keep the rice prices sufficiently low for the consumers (Budiyanti, 2017). As for the farmers, the government argues that by restricting imported rice, the domestic rice will stay dominant in the market, and benefit the farmers (Bulog, 2012; Hakim, 2016; The Jakarta Post, 2017).

The government implements the restrictions by granting the rights to import rice only to Bulog in accordance with its duty in price stabilization, disaster relief, and poverty alleviation as stipulated in MOT 103/2015 article 9 (1.b.). Prior to importing the rice, Bulog must receive formal authorization from the Ministry of Trade. This authorization can only be made after the ministerial coordination meeting on economic affairs as stipulated in the MOT 103/2015 article 9 (2) and article 10 (3). In several circumstances, the decision about rice import also depends on the direct order from the President (Faqih, 2015; Melani, 2015). This regulation stated that the private companies can only import specific types of rice for industrial purposes (article 12) and special dietary needs (article 18). As the result, this policy practically paves the way for Bulog to monopolize the business of rice import, while allowing the government to decide the timing of the import.

This study aims to explore policy options to lower rice prices in Indonesia by highlighting the potential of international trade. It also analyzes the shortcomings of price ceiling policy, and how Bulog could better perform its mandate in stabilizing rice prices by forming strategic partnerships with qualified private sector.

\section{METHODS}

A. Data description

The data for this study were derived from secondary sources. In selecting the variables, our model replicates Ravallion (1986) as well as Varela and Taniguchi (2014). We analyze the relationship between the logarithm (log) of domestic retail price (which means, same as consumer price, $P D)$ of the food items in Indonesia expressed in $\mathrm{Rp} / \mathrm{kg}$ and the log world price for same food items (PW) expressed in USD/kg, while controlling for movements expressed in Rupiah/US Dollar exchange rates (ER) also in logarithm form and all logarithms are natural. The average monthly data on retail prices $(\boldsymbol{P D})$ were obtained from the Statistics Indonesia (BPS) for the period May 2009 until May $2017 \quad$ (97 
observations). World prices (PW) were obtained from The World Bank Database (The Pink Sheet) for the same period. The nominal rupiah/dollar exchange rates (ER) were obtained from the $X$ Rates for same period.

B. Estimation approach

This paper combines the qualitative method and the quantitative method. For the qualitative method, we used secondary data from various textbooks, academic papers, and official reports as the main sources. This paper was also conducted by using semistructured interviews and focus group discussion with Indonesian Traditional Market Retailers Association (APPSI), Directorate General of Domestic Trade, Ministry of Trade, and ten rice retailers in the traditional markets of Blok $A$ and Cipete in DKI Jakarta. For the quantitative method, we apply timeseries modelling techniques and use error correction models (ECM). An ECM is a dynamic model in which the movement of the variables in any periods is related to the previous period's gap from long-run equilibrium (cointegrated). Furthermore, if the series is cointegrated, and the ECM validated, then it will encompass any other dynamic specification - such as the partial adjustment mechanism.
First step of the analysis entails testing the series of domestic and world prices and nominal exchange rates for unit roots, both in levels and first differences by using the Augmented Dickey-Fuller (ADF) tests. If both time series are not stationary, they are suitable to test for cointegration relationship between them. The next step entails estimating a long-run relationship between domestic prices (PD) and world prices (PW), while controlling for foreign exchange rates $(E R)$ is to use two-step method of (Engle and Granger, 1987), called symmetric ECM test. According to this approach, if the variables are cointegrated of the same order, then for those variables integrated of order one $(I(1))$ with a cointegration relation of the form as in equation (1):

$P D_{t}=\alpha_{0}+\beta_{1} P W_{t}+\beta_{2} E R_{t}+\varepsilon_{t} \ldots . .(1)$ would produce a stationary $\hat{\varepsilon}_{t}$ term (error term/residuals) after estimating this equation with an OLS (ordinary least square) procedure, where $\alpha$ and $\beta$ are estimated parameters. If the residuals of equation (1) are stationary, then an error correction mechanism exists.

Then, the ECM is specified by using lagged residuals from the cointegrating regression in equation (1) as 
error correction terms (ECT) and using $\Delta$

means subtracting $P_{t-1}$ from $P_{t}$ ) as as the difference indicator (differencing follows in equation (2):

$$
\begin{aligned}
& \Delta P D_{t}=\alpha_{0}+\beta_{1} \Delta P D_{t-1}+\beta_{2} \Delta P W_{t}+\beta_{3}(L) \Delta P W_{t-1}+\beta_{4} \Delta E R_{t}+\beta_{5}(L) \Delta E R_{t-1}+ \\
& \beta_{6} E C T_{t-1}+v_{t}
\end{aligned}
$$

\section{RESULTS AND DISCUSSION}

A. Rice in Indonesian economy and politics

As the staple food, rice has strategic values in economy and politics of Indonesia. High rice prices potentially generate domestic political instability as they form expectations on inflation and economic stability (Mariyono, 2014). These circumstances put the government in a delicate situation amidst the ongoing debate between those who are in favor of achieving food security via lower prices and trade liberalization, and those who prefer food self-sufficiency via greater import restrictions and high prices as they claim to protect local farmers from foreign competition (McCulloch \& Timmer, 2008).

This paper argues that there is more merit to food security than food selfsufficiency. Existing studies show that increasing rice prices do not translate into the increase of small farmers' family income and instead it hurts them along with all poor Indonesians (Cantrell, 2015; Makbul, Ratnaningtyas, \& Dwiyantoro,
2015; Patunru \& Basri, 2012). More than three-quarters of agricultural workers consume more rice than they produce, so the increase of rice prices would hurt rather than help them (McCulloch \& Timmer, 2008). In these circumstances, imposing food self-sufficiency may threaten to reverse the impact poverty alleviation programs, thus increasing the number of poor people in the country (Alavi, Htenas, Kopicki, Shepherd, \& Clarete, 2012).

Despite its negative impact on the poor, rice self-sufficiency is still part of the government's top priorities. President Joko Widodo even used rice self-sufficiency in his political campaign to presidency in 2014 (Widodo \& Kalla, 2014). Therefore, it is worth noting that Indonesian rice trade policy is driven not only by economic factors mentioned in the previous paragraph, but also by politics. In politics, most of the advocates of self-sufficiency maintain key positions in both government and private sectors (Basri \& Patunru, 2012, as cited in 
Cantrell, 2015). It also receives support from national farming and agricultural advocacy groups (Purwanto, 2013). While lacking in number compared to the poor (including small-scale farmers) who feel the negative impact of increasing rice prices, these groups are much more organized and influential in steering government policy (Patunru \& Basri, 2012). As the result, import restrictions on rice remain part of the current government food trade policy.

B. Rice prices in Indonesia and in the international market

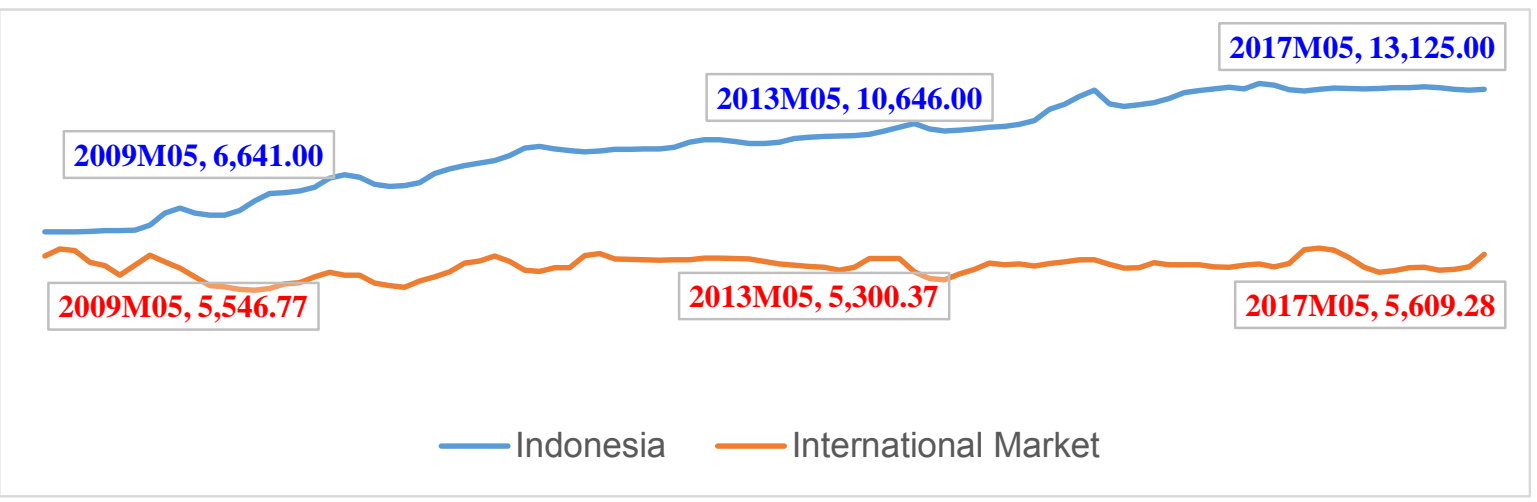

\section{Figure 2. The Trend of Rice Prices in Indonesia and in International Market}

Source: Statistics Indonesia (2009 - 2017), The World Bank (2009 - 2017), and X-rates.com (2017)

As mentioned in the previous section, rice self-sufficiency policy contributes to high rice prices in Indonesia compared to the international market. From May 2009 to May 2017, rice prices in Indonesia had different trajectories with the rice prices in the international market. In May 2009, rice prices in Indonesia were comparable with the international market at IDR 6,641 and IDR 5,546.77 respectively (Figure 2). In May 2013, rice prices in Indonesia increased by around $60.3 \%$ to IDR 10,646 per $\mathrm{kg}$, while the international market decreased by $4.4 \%$ to IDR 5,300.37 per kg. In May 2017, rice prices in Indonesia rose even further to IDR 13,125 per $\mathrm{kg}$, or nearly twice of its price in May 2009. On the other hand, the international market just increased by $1.12 \%$ to IDR $5,609.28$ per $\mathrm{kg}$. This amount was less than half of rice price in Indonesia in the same period. The disparity between rice prices in Indonesia and in the international market shows that Indonesian rice market is not integrated with its international counterpart.

Rice self-sufficiency policy imposed by the government forces the 
Indonesian market to primarily rely on the domestic production and diminishes the benefit of lower price offered by the international market. As the demand steadily increases along with the annual population growth of $1.14 \%$ (The World Bank, 2016), the domestic rice production is unable to meet it. These circumstances contribute to the increasing rice prices in Indonesian market against the trend in the international market. The disparity of rice prices in both markets will be further explained in the cointegration analysis below.

C. Cointegration results

Our observation shows that the relationships between the rice prices in Indonesia and in the international market in the long term (Equation 1) is different with their relationships in the short term (Equation 2).

As shown Equation 2, in the short term, for every $10 \%$ of price changes in the international market previous period, it will be followed by $1.09 \%$ of price changes in Indonesia current period. These changes occur when the prices either increase or decrease.

In the long term (Equation 1), the changes of rice prices in the International market does not have significant impact on the rice prices in Indonesia. These circumstances make rice prices in Indonesia deviate away from the prices in the international market, causing disconnection between them. Therefore, in the long term, rice prices in Indonesia are not determined by the international market. Other factors such as harvest failures, increasing prices of fertilizers, poor-quality of seeds, and the decreasing size of arable lands also play into factor. This would require further research to determine their impacts on rice prices in Indonesia.

Price $_{t}=-0.313+0.101$ PWrice $_{t}+1.038^{* * \star}$ ER $_{t}$

$\left.{ }^{* * *}\right)$ : denotes significance at $1 \%$ of confident level

$$
\begin{aligned}
& \Delta P \text { Drice }_{t}=0.004^{\star \star}+0.417^{\star * \star} \Delta \text { PDrice }_{t-1}+0.023 \Delta \text { PWrice }_{t}+0.109^{* \star *} \Delta \text { PWrice }_{t-1} \\
& +0.191^{\star \star} \Delta E R_{t}-0.033^{\text {** }} E C T_{t-1}
\end{aligned}
$$

$\left({ }^{* *}\right)$ : denotes significance at $5 \%$ of confident level 
D. The ineffective price ceiling policy

The price ceiling policy is unable to lower rice prices in the market. As this policy set rice prices below the equilibrium price, it distorts the markets and reduces economic welfare (McEachern, 2014). While specific academic studies on price ceiling in Indonesia has not been widely circulated, there are several existing studies highlighting the failure of similar policy in other countries. In Venezuela, government-imposed price controls on essential consumer products (including food) triggered black market activities and increased shortages from an average of $5 \%$ in 2003 to $41.3 \%$ in 2016 (Wu, 2016). These shortages contributed to the sharp price increase of maize flour, a staple food in Venezuela. Its prices rose tenfold from VEF 19 (USD 1.9) per kilogram in February 2015 to VEF 190 (USD 19) in May 2016 (Charner \& Clarke, 2016). In Ethiopia from January to May 2011, the government imposed price ceilings on 18 products, including sugar, palm oil, and wheat (Assefa, Abebe, Lamoot, \& Minten, 2016). Instead of lowering prices, this policy triggered shortages due to rationing issues, creating long queue in many parts of the country's capital in Addis Ababa.
The implementations of price ceilings on rice in Indonesia carry similar risk: If the production and distribution costs become higher than the price ceiling, the producers may reduce their outputs, and the distributors potentially hoard their supply to avoid losses. This will create supply shortage for the consumers, which will force them to turn to the black market where prices rise above the government price ceiling (Budiyanti, 2017; Fontinelle, 2017).

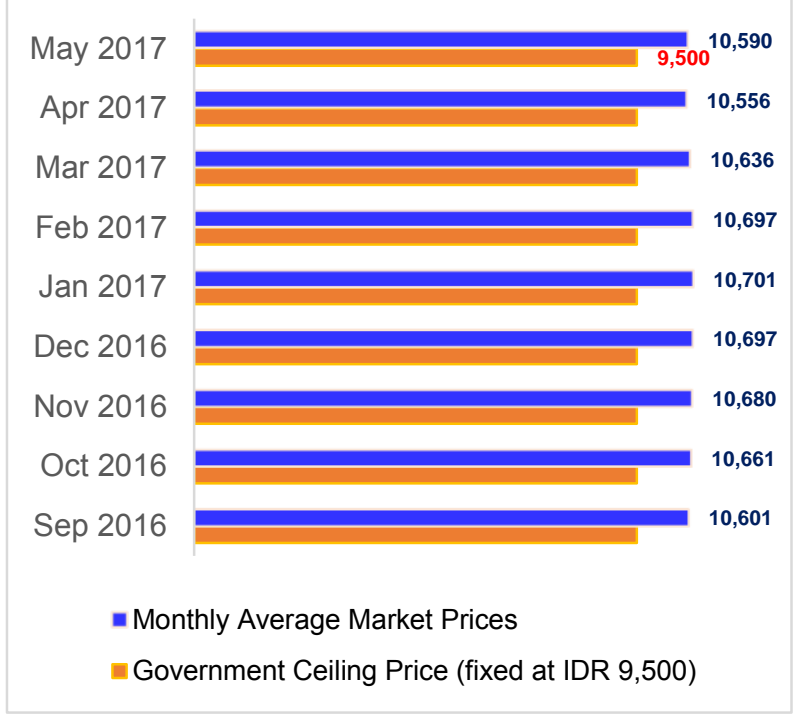

Figure 3. Monthly Average Rice Prices in the Consumers Market and Government Price ceiling

Source: Ministry of Trade (2017), MOT 63/2016 and MOT 27/2017 on Reference for Government Procurement and Maximum Retail Prices

Figure 3 shows that from September 2016 (the starting month of this policy) to May 2017, the monthly average prices in the consumer market 
were $12.07 \%$ more expensive than the price ceiling.

Rice retailers in several traditional markets in Jakarta were concerned that they would not be able to gain profit from their business if they sold the products using the price ceiling (Interviews, June 15-16, 2017). These rice retailers also expressed their reluctance because the wholesaler prices were already higher than the price ceiling. There is a risk of retailers blending the rice using low quality rice (such as Bulog's subsidized rice) in order for them to avoid losses.

Indonesian Traditional Market Retailers Association (Asosiasi Pedagang Pasar Seluruh Indonesia/APPSI) stated that their members cannot comply with price ceiling policy as they must deal with various surcharges such as transportation and labor cost in their transactions with the wholesalers (Medianti, 2017). Furthermore, these retailers must pay the wholesalers upfront. As the result, if the wholesalers sell their products to the retailers above the price ceiling, then the retailers must sell those products to the consumers at higher prices to gain profit (M. Maulana, Personal Interview, May 25, 2017).
E. Domestic rice distribution system is long, but does not truly benefit the retailers

One of the underlying problems with domestic rice is its long distribution system, involving different actors before rice could reach the consumers. At the farmers level as producers, since most of them are small-scale and poor (White, 2015), they rely on the services of middlemen and rice millers to get their harvested rice paddy processed and enter the next stage in the distribution system. In the aspect of distribution itself, the archipelagic nature of Indonesia requires the services of interisland rice traders to get rice across different parts of the country. Furthermore, such long transport would require storage, in which only major wholesalers with warehouses could provide it. These actors are integral part of domestic rice distribution system in Indonesia.

Domestic rice from the farmers must go through between four to six distribution actors before it could reach the consumers. First, the farmers sell their harvested rice paddy to the middlemen or to the paddy cutters, who dry the rice and sell them to the rice millers. After the rice is milled, the millers sell them to the major 
wholesalers who own warehouses to store the rice stock. These wholesalers then sell the rice to the smaller scale wholesalers in the provincial-level markets (such as Central Rice Market of Cipinang in DKI Jakarta Province), or to those who sell the rice to the different islands in Indonesia. These wholesalers sell the rice to the retailers, or in the case of Central Rice Market of Cipinang, the rice must go through the selling agents before they could reach the retailers. Only then, the consumers can purchase the rice in the market (Ariwibowo, 2013; Mahardika, 2013; Tambunan, 2008).

In each distribution system, either the middlemen, the rice millers, or the wholesalers receive the largest profit margin. In Java Island, their profit margin ranged around $60 \%$ to $80 \%$ per kg. Meanwhile, the retailers' profit margin only reached between $1.8 \%$ and 9.1\% per kg (Ariwibowo, 2013; Mahardika, 2013; Ruauw, 2015; Saragih, 2014). This situation shows that those who gains the largest profit are involved in the current distribution system before the rice gets into the retail market. In these circumstances, price ceiling policy would be ineffective since it only pushes the retailers to lower their rice prices while they are not the ones setting the price high. These circumstances show that domestic rice distribution system does not benefit either the farmers, retailers, or the consumers.

F. The potential of imported rice

As a large developing country, Indonesia has seen its economies transformed by trade as it becomes the engine of growth (Pangestu, 2014). Recent studies show that international trade openness in Indonesia has significant effect in both increasing economic growth (Tahir \& Azid, 2015) and decreasing poverty rate in the long run (Agusalim, 2017; Nursini, 2017).

In rice trade, however, those who favor trade liberalization and less import restrictions are often accused of betraying Indonesian farmers and acting in the interest of import mafia, rice mafia, or foreign groups (McCulloch \& Timmer, 2008). Yet historical record shows that Indonesia has been a rice importer for at least the past 100 years (Rosner \& McCulloch, 2008), with the share of imported rice compared to total rice in the country reached nearly $3 \%$ from 2011 to 2015 (Table 1). 
Table 1. Average Number of Domestic Production and Import of Rice, 2011 2015

\begin{tabular}{cccccc}
\hline Year & $\begin{array}{c}\text { Domestic } \\
\text { Paddy } \\
\text { Production } \\
\text { (tonnes) }\end{array}$ & $\begin{array}{c}\text { Converted } \\
\text { Paddy into } \\
\text { Rice (x 0.63) } \\
\text { (tonnes) }\end{array}$ & $\begin{array}{c}\text { Total } \\
\text { Imported } \\
\text { Rice } \\
\text { (tonnes) }\end{array}$ & $\begin{array}{c}\text { Total Rice } \\
\text { (Domestic } \\
\text { Rice + } \\
\text { Imported } \\
\text { Rice) } \\
\text { (tonnes) }\end{array}$ & $\begin{array}{c}\text { Proportion of } \\
\text { Imported Rice to } \\
\text { Total Rice }\end{array}$ \\
\hline 2011 & $65,756,904$ & $41,426,850$ & $2,750,476$ & $44,177,325$ & \\
2012 & $69,056,126$ & $43,505,359$ & $1,810,372$ & $45,315,731$ & $4.00 \%$ \\
2013 & $71,279,709$ & $44,906,217$ & 472,664 & $45,378,881$ & $1.04 \%$ \\
2014 & $70,846,465$ & $44,633,273$ & 844,163 & $45,477,436$ & $1.86 \%$ \\
2015 & $75,397,841$ & $47,500,640$ & 861,601 & $48,362,240$ & $1.78 \%$ \\
AVERAGE & $\mathbf{7 0 , 4 6 7 , 4 0 9}$ & $\mathbf{4 4 , 3 9 4 , 4 6 8}$ & $\mathbf{1 , 3 4 7 , 8 5 5}$ & $\mathbf{4 5 , 7 4 2 , 3 2 3}$ & $\mathbf{2 . 9 8 \%}$ \\
\hline
\end{tabular}

Sources: Statistics Indonesia (2016, 2017c) and Patunru (2017)

As for the allegation of import mafia or rice mafia, if we look at the prices, it is difficult to prove the existence of such mafia. For example, rice prices in DKI Jakarta reached IDR 11,450 per kilogram in September 2017, and continued to increase up to IDR 12,850 per kilogram in January 2018 (Indonesian Central Bank PIHPS, 2018). If such mafia exists, they should have released their rice stock into the market in January to collect their considerable profits of IDR 1,400 per kilogram, especially considering rice is perishable commodities. Afterwards, rice prices should have gone down in the following months. However, it did not happen as rice prices increased again in

2 This logic was proposed by Berly Martawijaya, an economist from the University of Indonesia and Program Director of Institute for
February 2018 up to IDR 14,000 per kilogram. $^{2}$

Without hard evidence of the existence of mafia, it would be wise if we look at the economic potential of imported rice. Compared to domestic rice, imported rice has shorter distribution system. While domestic rice needs between four to six distribution actors, imported rice only need at most three distribution actors to reach the consumers (Figure 4). From the importers, rice go either to the wholesalers/agents or the supermarkets. From wholesalers, the rice will go to the sub agents, then retailers, or it could even go straight from the wholesalers to the retailers. Afterwards, the consumers could (INDEF) (Martawijaya, 2018). 
purchase the rice from the retailers or the supermarkets (Kitano, Ariga, \& Shimato, 1999; Surjasa, Gumbira-Sa'id, Arifin, Sukardi, \& Jie, 2013) This short distribution system is possible because the imported rice is a processed, readyto-cook product, and therefore it does not require the role of paddy cutters, middlemen, nor rice millers in its distribution system.

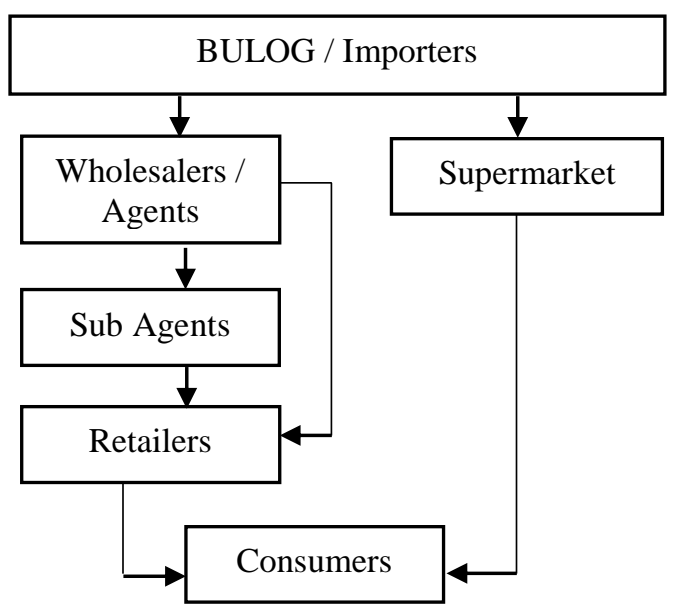

\section{Figure 4. Distribution Supply Chain of Imported Rice in Indonesia}

Source: Kitano et al. (1999) and Statistics Indonesia (2009), as cited in Surjasa et al. (2013)

While the reliable data for analyzing the profit margin of each distribution actors are yet to be available, the short length of imported rice distribution system shows that there are fewer distribution actors who may take advantage and gain profit from this system. Therefore, providing better access to imported rice may allow the consumers to purchase them at more affordable prices.

G. Bulog's bureaucratic constraints and financial situation

While the imported rice offers an alternative to lower rice prices for the consumers, Bulog is unable to seize this opportunity due to the bureaucratic constraints. While Bulog is mandated as the sole rice importer as part of its task in stabilizing rice prices, it must wait for the instruction from the President or from the ministerial coordination meeting before it could import the rice.

Consequently, Bulog could not decide when to import only by following the market situation, in which the best time to import a product is when its international prices are low as it would cost less compared to when the prices are high. As the result (Table 2), rice import by Bulog becomes a high-cost operation as it frequently imports rice at a large quantity when the international prices are already higher than the previous months (Statistics Indonesia, 2010 - 2017; The World Bank, 2010 2017).

The high prices Bulog pays for imported rice endanger its financial health. From the beginning of January 2010 to the end of December 2015, 
Bulog's debt grew by $74 \%$ from IDR 12.7 million to more than 22.1 million (Bulog, 2011 - 2015). During this period, Bulog's debts formed more than threequarter of its overall assets as its debts nearly four times higher than its equity on average. This situation shows that Bulog's financial situation is at high risk, signifying its inability to generate sufficient revenues from its business operations to sustain itself without relying on the government budget.

\section{Table 2. Estimated Cost and Potential Savings from Bulog's Rice Import, Nov}

2010 - Mar 2017

\begin{tabular}{cccc}
\hline $\begin{array}{c}\text { Time } \\
\text { Period }\end{array}$ & $\begin{array}{c}\text { Estimated Cost of } \\
\text { Import Spent by } \\
\text { Bulog (Billion IDR) }\end{array}$ & $\begin{array}{c}\text { Estimated Cost if the } \\
\text { Import Were Done } \\
\text { One Month Earlier } \\
\text { (Billion IDR) }\end{array}$ & $\begin{array}{c}\text { Estimated } \\
\text { Potential Savings } \\
\text { (Billion IDR) }\end{array}$ \\
\hline Nov 2010 & 890.88 & 840.02 & 50.87 \\
Dec 2010 & $1,398.92$ & $1,341.42$ & 57.50 \\
Sept 2011 & $1,296.82$ & $1,197.13$ & 99.69 \\
Dec 2012 & $2,601.43$ & $2,601.37$ & 0.06 \\
Jan 2013 & 252.69 & 249.45 & 3.24 \\
Oct 2014 & 482.37 & 478.98 & 3.39 \\
Dec 2014 & $1,210.64$ & $1,180.99$ & 29.64 \\
June 2015 & 341.41 & 340.76 & 0.65 \\
Jan 2016 & $1,957.04$ & $1,921.89$ & 35.15 \\
Feb 2016 & $1,538.11$ & $1,516.18$ & 21.93 \\
Mar 2017 & 155.07 & 153.79 & 1.29 \\
TOTAL & $\mathbf{1 2 , 1 2 5 . 3 8}$ & $\mathbf{1 1 , 8 2 1 . 9 7}$ & $\mathbf{3 0 3 . 4 1}$ \\
\hline Sources: Statistics Indonesia $(2010-2017)$ The World Bank $(2010-2017)$, and x-rates.com (2017)
\end{tabular}

H. Partnership with the private sector While Bulog must deal with its risky financial situation, there are private companies - that might include small and medium enterprises (SMEs) - who possess the capability to import rice, including the regular rice commonly consumed as staple food. In 2014, the government issued import permits for 13 private companies to import rice for industrial purposes (Agus, 2014;
Handoyo and Santosa, 2014; Mohamad, 2014). In the same year, they also grant import permits for 40 private companies to import rice for special dietary needs (Herlinda, 2014; JituNews.com, 2014; Kabar Bisnis.com, 2014).

These circumstances warrant the necessity for the government to make two key policy changes on the role of Bulog in importing rice. Firstly, since the 
government mandates Bulog to stabilize rice prices as stipulated in MOT $103 / 2015$ article 9 (b), then it should justify that policy by giving Bulog more freedom to determine the timing and quantity of rice import. The government should also reduce the bureaucratic procedures that Bulog must go through before it could import the rice. Therefore, the government should trust Bulog's judgment and its analysis on the rice market. Afterwards, they should allow this SOE to import rice without having to wait for instruction from the President or the coordination meeting between relevant ministries.

Secondly, to empower Bulog's decision-making process and to improve its market analysis on rice import, the government should establish publicprivate partnership between Bulog and qualified private sector. ${ }^{3}$ In this case, Indonesian government could learn from the experiences of Malaysia (Alavi et al., 2012). Malaysian government commissioned Malaysian Institute of Economic Research (MIER) to conduct focus group meetings with key stakeholders from the private sector, such as farmers, seed producers, rice

\footnotetext{
3 By qualified, it means the private companies involved in this partnership must at least have positive track record in rice trading, clear
}

millers, wholesalers, and retailers at separate occasions across the country. It also initiated meetings with relevant government officials at different times. The various inputs that MIER received from both public and private sector allowed them to formulate a comprehensive recommendation to the government on the best way to conduct rice trade policy in Malaysia.

Indonesia could follow along this approach, albeit in a slightly different way. While Indonesia already has multistakeholder Food Security Agency (Badan Ketahanan Pangan/BKP) that deals with the issues of domestic production and distribution, there is no formal consultative forum between Bulog and the private sector when it comes to the decision of importing rice. Therefore, Bulog should initiate coordination and consultative meetings not only with other government agencies, but also with the qualified private sector, including private rice importers, international trade analysts, and experts on the regional agricultural economic issues. By doing this, Bulog would be better equipped in determining the timing and quantity of rice import,

\footnotetext{
balance sheet showing its profit/loss in the recent years, as well as high quality human resources to do their job.
} 
and eventually helping Indonesia to be more integrated with the international rice market.

\section{CONCLUSION AND POLICY RECOMMENDATION}

Price ceiling policy on rice has not worked as intended as the average market price of this food item are still above the price ceiling. Furthermore, this policy unfairly puts the responsibility of lowering rice prices on retailers, while they only have much slimmer profit margins compared to the middlemen, the rice millers, and the wholesalers.

Considering the circumstances, it is recommended that the government conduct review on the effectiveness of this policy, especially to avoid any unintended consequences (e.g. black market activities) like what happened in Venezuela and Ethiopia.

Indonesia needs to take advantage of lower rice prices offered by the international market. Therefore, the government should authorize Bulog to make its own decision about the timing and the quantity of rice import without cumbersome bureaucratic procedures. To complement this, Bulog needs to improve its understanding and analysis on the rice market situation by conducting coordination and consultative meetings with the qualified private sector as what Malaysian government does via MIER. The private sector should at least include private rice importers, international trade analysts, and experts on the regional agricultural economic issues. By doing this, Indonesia would be more integrated with regional rice market, which then would allow rice prices in Indonesia to follow the low rice prices in the international market.

\section{ACKNOWLEDGEMENT}

We would like to extend our sincere gratitude to our colleagues at the Ministry of Trade and the Indonesian Traditional Market Retailers Association (APPSI) for sharing their expertise, experience, and information during our research. We also would like to convey our heartfelt thankfulness to our colleagues at the Center for Indonesian Policy Studies (CIPS) for their immense support and contribution in conducting this study.

\section{REFERENCES}

Agus, R. (2014, June 13). IMPOR BERAS: Kemendag Tunjuk 13 Importir Produsen [Rice Import: Ministry of Trade Appoints 13 ProducersImporters]. Retrieved August 9, 2017, from

http://industri.bisnis.com/read/201406 13/12/235727/impor-beraskemendag-tunjuk-13-importirprodusen

Agusalim, L. (2017). The Dynamic Impact of Trade Openness on Poverty: An 
Empirical Study of Indonesia's Economy. International Journal of Economics and Financial Issues, 7(1), 9.

Alavi, H. R., Htenas, A., Kopicki, R., Shepherd, A. W., \& Clarete, R. (2012). Trusting Trade and the Private Sector for Food Security in Southeast Asia. Washington D.C.: The World Bank.

Anti-Monopoly Commission [Komisi Pengawas Persaingan Usaha]. (2016). Struktur Industri dan Rantai Distribusi Komoditas [Industrial Structure and Commodities Chain of Distribution].

Ariwibowo, A. (2013). Analisis Rantal Distribusi Komoditas Padi dan Beras di Kecamatan Pati, Kabupaten Pati [Distribution Chain Analysis on Paddy and Rice in Pati District, Central Java]. Universitas Negeri Semarang, Semarang.

Ariyanti, F. (2016, February 1). Ini Penyebab Harga Bahan Pangan di RI Mahal [The Main Cause of Expensive Food Prices in Indonesia]. Retrieved June 8, 2017, from

http://bisnis.liputan6.com/read/2425

928/ini-penyebab-harga-bahanpangan-di-ri-mahal

Assefa, T., Abebe, G., Lamoot, I., \& Minten, B. (2016). Urban food retailing and food prices in Africa: the case of Addis Ababa, Ethiopia. Journal of Agribusiness in Developing and Emerging Economies, 6(2), 90-109. https://doi.org/10.1108/JADEE-022015-0009

Bank Indonesia [Indonesian Central Bank]. (2018, February 28). Pusat Informasi Harga Pangan Strategis [Information Center for Strategic Food Prices]. Retrieved February 28, 2018, from hargapangan.id

Bhinadi, A. (2012). Struktur Pasar, Distribusi, dan Pembentukan Harga Beras [Market Structure,
Distribution, and Price Formation of Rice]. Jurnal Ekonomi \& Studi Pembangunan [Journal of Economics and Development Studies], 13(1), 24-32.

Budiyanti, E. (2017). Dampak Kebijakan Penetapan Harga Eceran Tertinggi (HET) Komoditas Gula, Minyak Goreng, dan Daging Beku [The Impact of Maximum Retail Price Policy (HET) on Sugar, Cooking Oil, and Frozen Beef]. Majalah Info Singkat Ekonomi Dan Kebijakan Publik [Brief Report on Economics and Public Policy], IX(08). Retrieved from

http://berkas.dpr.go.id/puslit/files/inf o_singkat/Info\%20Singkat-IX-8-IIP3̈DI-April-2017-219.pdf

Bulog [National Logistics Agency]. (2011). Laporan Tahunan 2011 - 2015 [Annual Report 2011 - 2015].

Bulog [National Logistics Agency]. (2012). Impor Beras, Siapa Yang Diuntungkan [Who Benefits from Rice Import]. Retrieved July 3, 2017, from

http://www.bulog.co.id/berita/37/216 4/10/11/2010/Impor-Beras,-SiapaYang-Diuntungkan.html

Cantrell, B. (2015). Food, the State and Development: A Political Economy of Agriculture and Trade in Indonesia (Thesis).

Charner, F., \& Clarke, R. (2016, August 2). Venezuela: Where flour, pasta and milk can cost a month's pay CNN.com. Retrieved July 5, 2017, from http://edition.cnn.com/2016/08/02/a mericas/venezuela-foodprices/index.html

Engle, R. F., \& Granger, C. W. J. (1987). Co-integration and Error Correction: Representation, Estimation, and Testing. Econometrica, 55(2), 251276. http://dx.doi.org/10.2307/1913236

Faqih, F. (2015, September 22). JK wacanakan impor beras, mentan 
tunggu instruksi Presiden Jokowi | merdeka.com. Retrieved August 4, 2017, from https://www.merdeka.com/uang/jkwacanakan-impor-beras-mentantunggu-instruksi-presidenjokowi.html

Fontinelle, A. (2017). The Mechanics of the Black Market. Retrieved from http://www.investopedia.com/article s/economics/12/mechanics-blackmarket.asp

Hakim, L. (2016, March 23). Kebijakan Proteksi Impor yang Salah Sasaran [Mistargeted Policy on Import Restrictions]. Retrieved July 3, 2017 , from https://suarakebebasan.org/id/opini/ item/601-kebijakan-proteksi-imporyang-salah-sasaran

Handoyo, \& Santosa, U. A. (2014, June 15). Kemdag izinkan impor beras khusus ke 13 perusahaan [Ministry of Trade grants permits to 13 companies to import rice]. Retrieved August 9, 2017, from http://nasional.kontan.co.id/news/ke mdag-izinkan-impor-beras-khususke-13-perusahaan

Herlinda, W. D. (2014, June 11). 40 Importir Beras Telah Kantongi Status IT [40 Rice Importers Receive Status as Registered Importers]. Retrieved August 8, 2017, from http://industri.bisnis.com/read/2014 0611/12/235167/40-importir-berastelah-kantongi-status-it

Jefriando, M. (2016, June 14). Rantai Distribusi Terlalu Panjang, "Biang Kerok" Harga Beras Mahal [Long Chain of Distribution Makes Rice Prices Expensive]. Retrieved June 8, 2017, from http://finance.detik.com/beritaekonomi-bisnis/3131996/rantaidistribusi-terlalu-panjang$\% 27$ biang-kerok\%27-harga-berasmahal

JituNews.com. (2014, June 11). Kemendag Keluarkan Izin Impor
Beras [Ministry of Trade issue permits to import rice]. Retrieved August 9, 2017, from http://www.jitunews.com/read/2217/ kemendag-keluarkan-izin-imporberas

KabarBisnis.com. (2014, June 12). 40 Perusahaan resmi kantongi izin impor beras [40 private companies receive permits to import rice]. Retrieved August 9, 2017, from http://www.kabarbisnis.com/read/28 48048/40-perusahaan-resmikantongi-izin-impor-beras

Kitano, N., Ariga, H., \& Shimato, H. (1999). Current Situation of Rice Distribution System in Indonesia Executive Summary. Japan Bank for International Cooperation. Retrieved from https://www.jica.go.jp/jicari/IFIC_and_JBICI-Studies/jicari/publication/archives/jbic/report/pa per/pdf/rp05_e.pdf

M. Maulana. (2017, May 25). Personal interview with the Secretary General of the Indonesian Traditional Market Retailers Association (APPSI).

Mahardika, T. K. S. (2013). Kajian Distribusi Beras di Wilayah DKI Jakarta Melalui Pasar Induk Cipinang [Analysis on Rice Distribution in DKI Jakarta via Cipinang Central Rice Market]. Institut Pertanian Bogor [Bogor Agricultural Institute], Bogor.

Makbul, Y., Ratnaningtyas, S., \& Dwiyantoro, P. (2015). The effect of Market structure on the integration of rice prices with paddy prices and its impact on farmers family income in the Kroya District, Indramayu Regency, Indonesia. The Journal of Developing Areas, 49(3), 217-228.

Mariyono, J. (2014). The Economic Performance of Indonesian Ricebased Agribusiness. International Journal of Administrative Science and Organization, 21(1), 35.

Martawijaya, B. (2018, January). Presented at the Diskusi Bulanan 
Ikatan Alumni Universitas Indonesia (lluni) mengenai Impor Beras [Monthly Discussion of the Alumni of the University of Indonesia on Rice Import].

Masa, A. (2017, April 17). Pemerintah akan tindak tegas peritel langgar harga eceran tertinggi [The government will implement strict sanctions on retailers who disobey ceiling price policy]. Retrieved July 5, 2017, from http://www.antaranews.com/berita/6 24596/pemerintah-akan-tindaktegas-peritel-langgar-harga-ecerantertinggi

McCulloch, N., \& Timmer, C. P. (2008). RICE POLICY IN INDONESIA: A SPECIAL ISSUE. Bulletin of Indonesian Economic Studies, 44(1), 33-44. https://doi.org/10.1080/0007491080 2001561

McEachern, W. A. (2014). Macroeconomics: a contemporary introduction.

Medianti, U. S. (2017, May 17). APPSI: Aturan HET Bunuh Pelan-pelan Pedagang Pasar [APPSI: HET Slowly Kills Traditional Market Retailers]. Retrieved July 3, 2017, from

http://ekonomi.inilah.com/read/detai 1/2379283/appsi-aturan-het-bunuhpelan-pelan-pedagang-pasar/

Melani, A. (2015, May 12). Seskab Andi: Arahan Presiden Jokowi Tak Impor Beras. Retrieved August 4, 2017, from

http://bisnis.liputan6.com/read/2230 753/seskab-andi-arahan-presidenjokowi-tak-impor-beras

Ministry of Trade. (2016). Laporan Kinerja 2016 Direktorat Jenderal Perdagangan Dalam Negeri, Kementerian Perdagangan [2016 Performance Report - Directorate General of Domestic Trade, Ministry of Trade].
Ministry of Trade. (2017, May 8). Grafik Harga Kebutuhan Pokok Nasional [Graph on Prices of National Strategic Commodities]. Retrieved May 9, 2017, from http://www.kemendag.go.id/id/econ omic-profile/charts/national-pricechart

Mohamad, A. (2014, June 13). Keran impor beras premium dibuka buat 13 perusahaan [The government opens the import of premium rice for 13 companies]. Retrieved August 9, 2017, from https://www.merdeka.com/uang/ker an-impor-beras-premium-dibukabuat-13-perusahaan.html

Nursini, N. (2017). Effect of Fiscal Policy and Trade Openness on Economic Growth in Indonesia: 1990-2015. International Journal of Economics and Financial Issues, 7(1), 358-364.

OECD, \& FAO. (2015). OECD-FAO Agricultural Outlook 2015. OECD Publishing.

https://doi.org/10.1787/agr_outlook2015-en

Pangestu, M. (2014). Challenges of the world trading system and implications for Indonesia. In P. Athukorala, A. A. Patunru, \& B. P. Resosudarmo (Eds.), Trade, Development, and Political Economy in East Asia. ISEAS Publishing.

Patunru, A. A. (2017, August). On the rice fracas in Indonesia. Presented at the Indonesia Study Group, Canberra.

Patunru, A. A., \& Basri, M. C. (2012). The Political Economy of Rice and Fuel Pricing in Indonesia. In A. Ananta \& R. Barichello (Eds.), Poverty and Global Recession in Southeast Asia. Singapore: ISEAS Publishing.

Pradana, R. S. (2015, November 12). Dugaan Kartel Beras, KPPU: Pedagang Besar Berisiko Oligopoli [Allegation on Cartel Practices in Rice Market, Oligopolistic Most Likely Occur Among the 
Wholesalers,

Anti-Monopoly

Commission Said]. Retrieved June

9, 2017, from

http://industri.bisnis.com/read/2015

1112/12/491551/dugaan-kartel-

beras-kppu-pedagang-besar-

berisiko-oligopoli

Presidential Office. (2017, June 13). Negara Harus Hadir untuk Kesejahteraan Petani [The State Must Be Present to Ensure Farmers' Welfare]. Retrieved July 3, 2017, from /berita-aktual/negara-harushadir-untuk-kesejahteraanpetani.html

Purwanto, H. (2013). Local To Global; How Serikat Petani Indonesia Has Accelerated The Movement For Agrarian Reform. La Via Campesina's Open Book: Celebrating 20 Years of Struggle and Hope, 1-12.

Ravallion, M. (1986). Testing Market Integration. American Agricultural Economics Association, 68(1), 102109.

https://doi.org/10.2307/1241654

Rice Retailers in the Traditional Markets of Blok A and Cipete in DKI Jakarta. (2017, June 15). Personal interview with rice retailers in the traditional markets of Blok $A$ and Cipete in DKI Jakarta.

Rosner, L. P., \& McCulloch, N. (2008). A NOTE ON RICE PRODUCTION, CONSUMPTION AND IMPORT DATA IN INDONESIA. Bulletin of Indonesian Economic Studies, 44(1), 81-92. https://doi.org/10.1080/0007491080 2001595

Ruauw, E. (2015). Kajian Distribusi Pangan Pokok Beras di Kabupaten Kepulauan Talaud [Analysis on Rice Distribution System in Talaud Islands District, North Sulawesi Province]. Agri Sosio Ekonomi, 11(1), 58-68.

Sagala, J. J., \& Adri. (2017, March 21). Personal interview with the officials of the Directorate General of Domestic Trade, Ministry of Trade.

Saragih, A. E. (2014). Analisis Sistem Pemasaran Beras Ciherang di Kecamatan Cibeber, Kabupaten Cianjur. Institut Pertanian Bogor [Bogor Agricultural Institute], Bogor. Retrieved from http://repository.ipb.ac.id/jspui/bitstr eam/123456789/70795/1/H14aes.p df

Statistics Indonesia. (2009). Laporan Hasil Survei Pola Distribusi Perdagangan 16 Komoditi di 15 Provinsi [Survey Report on Trade Distribution Pattern of 16 Commodities in 15 Provinces in Indonesia].

Statistics Indonesia. (2010). Buletin Statistik Perdagangan Luar Negeri Impor - Januari 2010 s/d Maret 2017 [Foreign Trade Statistical Bulletin Imports - from January 2010 to March 2017]. Retrieved from https://www.bps.go.id/website/pdf_p ublikasi/Buletin-Statistik-

Perdagangan-Luar-Negeri-ImporMaret-2017--.pdf

Statistics Indonesia. (2016). Statistik Indonesia $2016 \quad$ [Statistical Yearbook of Indonesia 2016].

Statistics Indonesia. (2017a). Laporan Bulanan Data Sosial Ekonomi. Jakarta. https://doi.org/9199017

Statistics Indonesia. (2017b). Pengeluaran untuk Konsumsi Penduduk Indonesia - Buku 1 Maret $2017 \quad$ [Consumption Expenditure of Population of Indonesia - First Book - March 2017].

Statistics Indonesia. (2017c). Statistik Indonesia $2017 \quad$ [Statistical Yearbook of Indonesia 2017]. Statistics Indonesia.

Surjasa, D., Gumbira-Sa'id, E., Arifin, B., Sukardi, \& Jie, F. (2013). Indonesian rice supply chain analysis and supplier selection model. International Journal of Information, 
Business and Management, 5(1), 198.

Tahir, M., \& Azid, T. (2015). The relationship between international trade openness and economic growth in the developing economies: Some new dimensions. Journal of Chinese Economic and Foreign Trade Studies, 8(2), 123-139. https://doi.org/10.1108/JCEFTS-022015-0004

Tambunan, T. (2008, September). Tata Niaga dan Pengendalian Harga Beras di Indonesia. Indonesia Chamber of Commerce [KADIN]. Retrieved from http://www.kadinindonesia.or.id/enm/images/dokum en/KADIN-98-3145-26092008.pdf

The Jakarta Post. (2017, June 14). "Food sovereignty begins with farmers" welfare in mind'.

The World Bank. (2009). The World Bank Commodities Price data (The Pink Sheet) - from May 2009 to May 2017. Retrieved from http://www.worldbank.org/commodit ies

The World Bank. (2015). Indonesia's Rising Divide - Executive Summary.

The World Bank. (2016). Population growth (annual \%). Retrieved February 28, 2018, from

The World Bank. (2017). The World Bank Commodities Price Data (The Pink Sheet).

UN-FAO. (2001). Food Balance Sheets $A$ Handbook. Retrieved from http://www.fao.org/docrep/003/x989 2e/x9892e00.htm
Varela, G. J., \& Taniguchi, K. (2014). Asymmetric Price Transmission in Indonesia's Wheat Flour Market (ADB ECONOMICS WORKING PAPER SERIES No. 394). ADB Economics Working Paper Series (Vol. 394). Manila.

White, B. (2015). Meneliti Masalah Petani dan Pangan pada Tingkat Lokal: Pengantar Studi Kemandirian Pangan Akatiga [Investigating Farmers and Food Problems at the Local Level: AKATIGA's Introduction Study on Food SelfSufficiency]. Jurnal Analisis Sosial [Journal on Social Analysis], 19(1), 1-10.

Widodo, J., \& Kalla, J. (2014). Visi, Misi, dan Program Aksi - Jokowi \& Jusuf Kalla 2014 [Vision, Mission, and Action Programs of Joko Widodo and Jusuf Kalla 2014].

Wu, M. B. (2016). Issues in Venezuelan Monetary and Economic Reform. Studies in Applied Economics Johns Hopkins University, (62). Retrieved from http://sites.krieger.jhu.edu/iae/files/2 017/04/Issues-in-VenezuelanMonetary-and-EconomicReform.pdf

X-Rates. (2017). X-Rates Converter Exchange Rates. Retrieved February 14, 2017, from http://www.xrates.com/average/?from $=$ USD\&to= IDR\&amount $=1 \&$ year $=2010$ 
